\title{
Beyond practitioner and researcher: 15 roles adopted by actors in transdisciplinary and transformative research processes
}

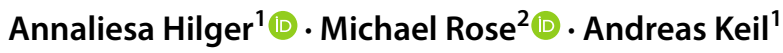

Received: 8 February 2021 / Accepted: 12 August 2021 / Published online: 18 October 2021

(c) The Author(s) 2021

\begin{abstract}
To tackle complex sustainability problems, science and practice must join forces and interact in the processes of knowledge co-production. This central claim of sustainability science requires all actors to do more than simply participate in a workshop or carry out traditional research. It is essential to provide clarity to actors about the roles to adopt in these processes, especially in terms of planning collaborations - with whom, when, and how. Therefore, in this paper we identify, describe, and discuss 15 roles for actors involved in such processes. We undertook a systematic literature review to identify papers with precise descriptions of transdisciplinary (td) and transformative (tf) research processes. We focused on the common occurrence of activities undertaken by actors by applying 72 activity codes a total of 549 times. Subclusters of activities were identified by means of a hierarchical cluster analysis and these were condensed into 15 roles. The roles can be categorised in four activity realms: field, academia, boundary management, and knowledge co-production. The roles of the Data Supplier, the Field Expert, and the Application Expert are adopted by actors who originate from the field, whereas the roles of the Scientific Analyst and the Knowledge Collector are primarily adopted by researchers. Furthermore, we identified 10 roles within the activity realms of the knowledge co-production process and boundary management. The high number and diversity of roles, especially in the realm of boundary management, reveals the importance of a comprehensive approach to coordination, communication, and process design.
\end{abstract}

Keywords Non-scientific actors $\cdot$ Role descriptions $\cdot$ Knowledge co-production $\cdot$ Boundary management $\cdot$ Systematic review $\cdot$ Stakeholder

\section{Introduction}

Sustainable development requires a deep partnership between science and practice. This claim has been an important part of the discourse of sustainability from the outset, as reflected, for example, in Chapter 31 of the Agenda

Handled by Daniel J. Lang, Leuphana University of Lueneburg, Germany.

Annaliesa Hilger

ahilger@uni-wuppertal.de

Michael Rose

rose@leuphana.de

https://www.leuphana.de/michael-rose

1 Institute of Geography and Primary Social and Science Education, University of Wuppertal, Gaußstr. 20, 42119 Wuppertal, Germany

2 Institute of Sustainability Governance, Leuphana University of Lüneburg, Universitätsallee 1, 21335 Lüneburg, Germany
21 (United Nations Conference on Environment and Development [UNCED] 1992, 31.1) Consequently, collaboration with non-scientific actors ${ }^{1}$ is one of the central principles of sustainability science, where "research must be created through processes of co-production in which scholars and stakeholders interact to define important questions, relevant evidence, and convincing forms of argument" (Kates et al. 2001, p. 2).

This debate about the mission of science (and research approaches) in society (Jahn et al. 2012; Kates et al. 2001; Miller 2013; Miller et al. 2014; Schneidewind et al. 2016; Schneidewind and Augenstein 2016; Scholz 2017; Stoecker 1999 ) is reflected in a growing amount of transdisciplinary (td) and transformative (tf) research processes and

\footnotetext{
1 As the aim of this paper is to identify the roles of actors involved without any presuppositions, we use the neutral term "non-scientific actors". This avoids the attribution of a certain function, activity, knowledge, or even role and instead refers to the fact that those actors are not responsible for the scientific part of the process, although they might have academic training or academic institutional backgrounds.
} 
corresponding publications. Transdisciplinarity is understood here as a critical and self-reflexive research approach, which integrates different interdisciplinary scientific and extra-scientific insights to co-produce new knowledge to tackle complex problems (Jahn et al. 2012, pp. 8-9). Transformative research focuses more explicitly on societal impact and views the production of scientific knowledge "as a form of societal intervention that aims at catalysing societal change processes" (Schneidewind et al. 2016, pp 7-8).

In fact, $t d$ and tf research processes vary enormously; this is due partly to different approaches or schools (Scholz 2017), but also to the different realities of collaborative research projects. These variations are influenced by factors such as funding schemes, the problem to be studied, and the institutional framework. Despite differences, a common feature of all approaches is a shared space where nonscientific actors and researchers meet to collaborate, share, and produce knowledge: e.g. conceptualised as a 'transition arena', a 'space of social learning', or an 'agora' - depending on the specific approach (Wittmayer and Schäpke 2014). In this shared space, "the boundaries between the classical epistemological realms and corresponding roles of scientific and non-scientific actors are blurred" (Pohl et al. 2010, p. 269), which makes it important to study the roles adopted by actors within these research processes. Defined roles within these processes provide the actors in the field with a "vocabulary", which enables transparency towards others (Wittmayer and Schäpke 2014, p. 493). Our analysis focuses on these td and tf interaction processes and the activities and roles therein (and less on the research activities themselves).

$\mathrm{Td}$ or tf research processes can be a new experience for the actors involved: the activities may diverge from the everyday work of the actors and they may not have familiar approaches, best practice examples or role models to guide their interactions, resulting in uncertainties and/or diverse expectations. For researchers, transdisciplinarity creates a "research borderland" (Felt et al. 2013, p. 522) where they are faced with competing demands, such as scientific rigour vs. societal relevance, which can endanger their autonomy (Rose and Maibaum 2020; Schäpke et al. 2016; Stauffacher 2010). Defined roles have the potential to unburden researchers from the need to meet all these competing demands, especially when the roles have already been formulated during the planning stage of a collaboration. For non-scientific actors, defined roles provide clarity on what to expect in the collaboration and what might be expected of them. In general, dedicated reflection and transparency enables all actors to perform their roles confidently, freeing them from arbitrary or unclear expectations of themselves or others.

Literature on the roles of non-scientific actors in td and tf research processes is rare, except for a few articles explicitly discussing the roles attributed by researchers to non-scientific partners (Felt et al. 2012; Klenk and Meehan 2017; Newton and Elliott 2016). In contrast, a few works do go into detail about the roles of researchers within the td and tf research process (Bulten et al. 2021; Hilger et al. 2018; Horlings et al. 2020; Pohl et al. 2010; Sarkki et al. 2013; Stoecker 1999; Wittmayer and Schäpke 2014) and also discuss the existence of the "boundary management" activities that can be performed by different actors (e.g. Cash et al. 2003; Fischer and Newig 2016). However, the literature to date tends to take as its starting point previously defined role conceptions, which are already assigned to certain actor groups. Lacking are studies on the roles of all actors involved in td and tf research processes, without assumptions about which actor groups perform which roles. This research gap is crucial, as a single role is always part of a constellation of roles that interact with each other (Wittmayer et al. 2017, pp. 51-52); this inter-relationship could be misrepresented by limiting analysis to only certain actor groups and their designated roles. In addition, previous research draws on only small numbers of processes when conceptualising roles.

By investigating the roles of all actors involved in td and tf research processes, we aim to address this research gap and contribute to transparent research practices. We start by capturing the breadth of activities in scientific/non-scientific interactions (without considering the actors involved), and then identify different clusters of activities. Finally, we associate these activities with the different roles and, ultimately, with those actors who usually perform the roles. By taking the activities as a starting point (as opposed to the role conceptions already linked to certain actors), our paper goes beyond the recent approach of merely considering the perspective of certain actor groups. Instead, we propose a change of perspective towards considering all the roles potentially required for a fruitful collaborative process in an integrative manner. Furthermore, our study is based on a reasonable number of different processes, with the result that specific individual processes have less influence on our conceptualisation. To this end, we conduct a systematic literature review of empirical papers that contain sufficient information on actors' activities observed in real-world td and $\mathrm{tf}$ research processes in the realm of sustainability. We code all activities observed in these studies and employ a hierarchical cluster analysis to help us identify co-occurring activities that can be aggregated into coherent roles.

The paper is structured as follows: in the next section, we discuss existing research and review the theoretical concept of roles in general. In the following section, we outline our methodological approach, which includes a systematic literature review and a cluster analysis. We then describe the 15 identified roles and discuss the limits of our paper and the consequences for future $t d$ and $t f$ research processes, before presenting our conclusions. 


\section{Role theory and actor concepts}

\section{Role theory for $t d$ and $t$ research processes}

Role theory aims to identify ideal types of behaviour from a number of people and, consequently, to describe role characteristics (Biddle 1979; Schimank 2016; Wittmayer 2016). Roles are understood as "those behaviors that are characteristic of a set of persons and a context" (Biddle 1979, pp. 58-59). More precisely, Wittmayer (2016, p. 105) defines roles "as a set of recognizable activities and attitudes used by an actor to address recurring situations". The performance of a role relies on an actor's knowledge about that role and the perceived behavioural expectations of reference groups (Biddle 1979, 4-6; Schimank 2016, p. 47). According to Biddle (1979, p. 8), people perform roles consciously. In summary, roles can be identified by observing actors' activities in recurring situations.

Roles are socially constructed and "therefore open to negotiation and change" (Wittmayer 2016, p. 105). Furthermore, roles are not easily distinguishable as they overlap in practice and are a continuum - rather than being separate and distinct from each other-as the activities performed in different roles are complex and fluid (Horlings et al. 2020, p. 469; Wittmayer and Schäpke 2014, p. 492). In addition, a single role is part of a constellation of roles that interact and co-evolve with each other (Wittmayer et al. 2017, pp. 51-52). This is especially important from a community perspective; for example, as highlighted by Stoecker (1999, p. 847), researchers often occupy roles that are lacking within the community. Furthermore, roles are defined contextually and are, therefore, limited by the contextual boundaries in how far they can be applied (Biddle 1979, pp. 58-59). The same actor can perform different roles in different-and possibly recurring — situations.

Role theory differentiates between the processes of "role-taking" and "role-making". Role-taking is normally observed in situations with clear expectations, whereas role-making comes to the fore in complicated situations that require the actors to be creative in establishing their own roles (Schimank 2016, p. 55). Complications can include conflicts within or between roles, a lack of role knowledge, or a lack of resources (Biddle 1979, p. 8; Schimank 2016, pp. 56-63). Overall, role-taking tends to occur in situations with clear, consistent, and perceived expectations, whereas role-making is common in situations characterised by uncertainty and a range of divergent expectations. Accordingly, both role-taking and role-making are likely to occur in td and tf research processes.

Both articulated and perceived expectations have a significant influence on role designations. Felt et al. (2012, pp. 15-16), for example, note that researchers expected non-scientific actors to undertake a number of different roles. This aspect is crucial, as the designation of roles enables the exercise of power, not only in terms of selecting and assembling actors but also "in the definition of the roles [...] and their respective positioning" (Fritz and Binder 2020: 7).

\section{Actor groups and roles in td and tf research processes}

The differences within and between tf and td approaches, as previously mentioned, become apparent in the variety of terms used for the actors involved. For non-scientific actors in particular, there are a number of "fluid classifications" (Bracken et al. 2014, p. 1293). These classifications sometimes provide information about the intensity of involvement of the non-scientific actors or the activities they undertake. The use of a specific term could also hint at "the underlying thoughts" (Mobjörk 2010, p. 871) and goes hand in hand "with particular forms and theories of public participation" (Chilvers and Longhurst 2016, p. 589).

Some scholars divide the non-scientific actor group into "practitioner" and "the public at large" (e.g. Ober et al. 2019; Scholz 2020, p. 246; Stauffacher and Scholz 2012, p. 285; Wesselink et al. 2011). The German term "Praxispartner" (practice partner resp. practitioner) is widely used and is often "the central actor in researchers' narratives" (Felt et al. 2012, p. 15). This actor should be closely related to the context of application and/or hold context-specific knowledge of the field: often constructed as the central counterpart to the researcher, this actor is expected to be embedded in the field. Associated activities include providing contacts and access to people in the field and contributing strategic knowledge. This "practitioner" is often constructed as a central actor during the knowledge co-production phase, and the activities include involvement in defining and agreeing on a common problem perception and a research question, as well as translating and perhaps disseminating the research results into the application context. Collectives, such as "society" or "the public", are seen as the primary beneficiaries of td and tf research processes, as well as - more specifically"interested people" or "affected groups" (Felt et al. 2012).

These terms for actors involved in td and tf research processes reveal that td and tf scholars tend to designate individual actor groups with a certain a function and activity within the process, which equates more or less to the designation of a specific role. There are a limited number of studies on role attributions (for an overview, see Table 1). For example, Felt et al. (2012) identified in the funding proposals and in the researchers' ex-post narratives four roles that researchers expected their non-scientific partners to adopt: "gatekeeper", "data-supplier", "assessment-agent", and "multipliers and communicators". Klenk and Meehan (2017) also identified several 


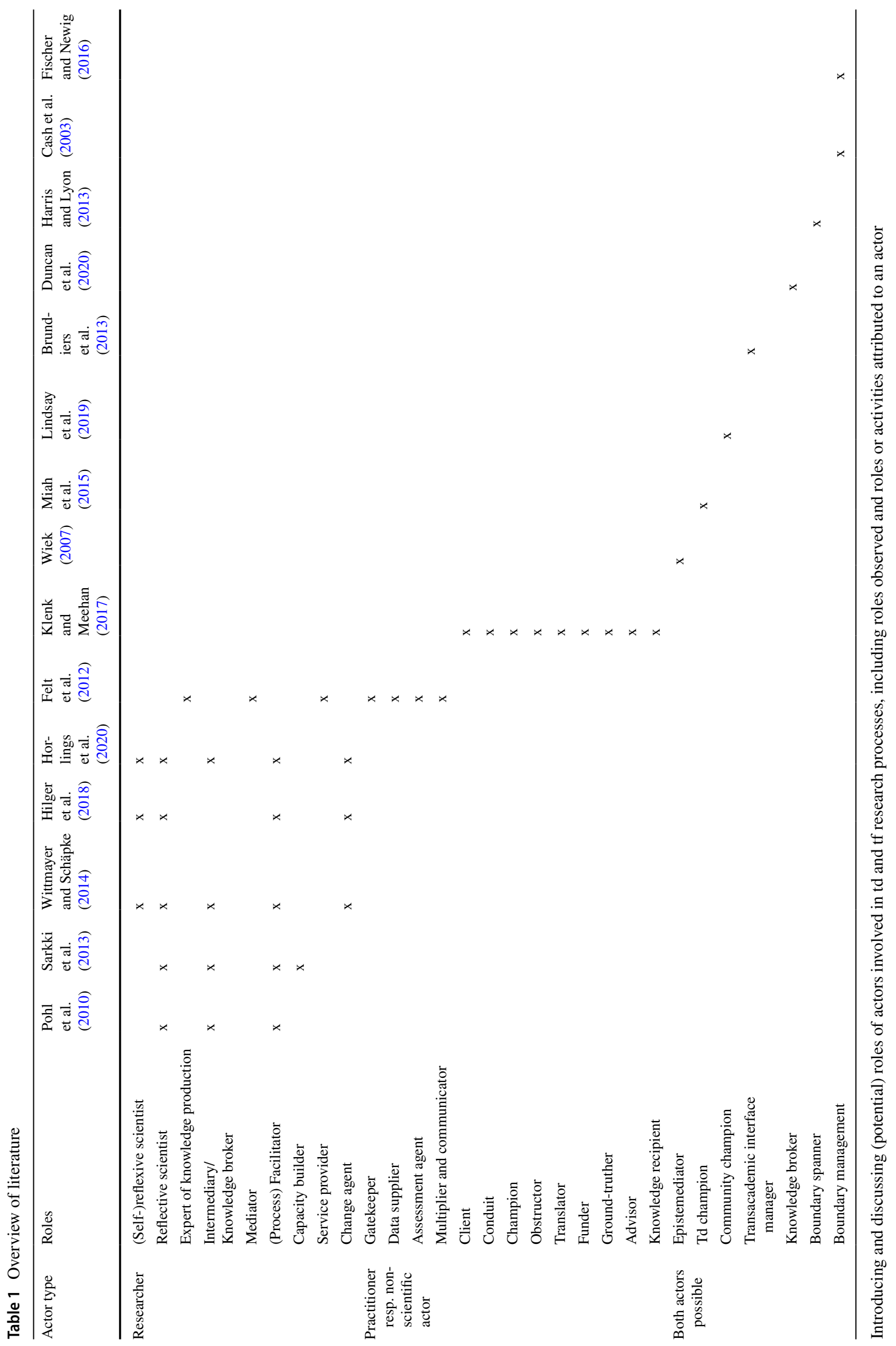


roles that researchers expected non-scientific actors to adopt: "advisor", "champion", or "conduit" (who ideally translate the process results into decision-making processes) and "recipients", "translators", or "ground-truthers" (who contribute 'on-the-ground' knowledge and expertise). From another angle, Fritz and Binder (2020) stress that non-scientific actors can also allocate activities to researchers. However, no studies have systematically investigated roles played by non-scientific actors that are empirically observed (as opposed to merely attributed).

The literature on the roles of researchers describes up to six different roles (for an overview, see Table 1). The role of the "reflective scientist" comprises the provision of expertise based on scientific knowledge produced according to the quality criteria of scientific disciplines. Researchers in the role of the "(process) facilitator" enhance communication and enable learning processes within the co-production of knowledge (Pohl et al. 2010, p. 277). The role of the "intermediary" (Pohl et al. 2010, p. 277) or "knowledge broker" (Wittmayer and Schäpke 2014 , p. 488) differs from the "facilitator" in its focus on knowledge integration; it is described as a role which translates the different knowledge styles or thought collectives and makes them visible in order to integrate knowledge. The process-oriented roles of the "intermediary" and the "facilitator" reflect the importance of a thorough and well-designed process and can be undertaken by different actors (Pohl et al. 2010, p. 277). In addition, Wittmayer and Schäpke (2014) introduced the role of the "change agent", who is more actively involved in the real-world problem or intervention, and complemented this with the role of the "(self-)reflexive scientist", who reflects on the influence of their own personality and normativity. Sarkki et al. (2013) introduced the role of the "capacity builder", who focuses on training the participants to implement the co-production processes independently (Sarkki et al. 2013, p. 191).

In addition to the discourse on the roles of researchers, there is a broad range of literature which discusses institutions or roles that arbitrate between the realms of science and society (see Table 1). The term used for this role varies depending on its specific manifestation; for example, Wiek (2007, p. 56) referred to the "epistemediator", whereas Miah et al. (2015) described the "transdisciplinary champion" and Lindsay et al. (2019) used the term "community champion" (Lindsay et al. 2019). Similar approaches also discuss this type of role, e.g. the role of the "transacademic interface manager" in the educational context (Brundiers et al. 2013, p. 4614), the "knowledge broker" in the context of science policy boundaries (Duncan et al. 2020, p. 477), or the "boundary spanner", who acts as a facilitator between different professional cultures (Harris and Lyon 2013, p. 115). According to Cash et al. (2003, pp. 8087-8088), this "boundary management" role includes the functions of communication, translation, and mediation. Based on their literature review, Fischer and Newig (2016) also concluded that the common feature of this role is the mediating function.

\section{Methods}

\section{Material}

A systematic literature review was carried out to identify the material for analysis (Efron and Ravid 2019; Moher et al. 2009; Snyder 2019). The data sought can be characterised as follows: peer-reviewed articles in English, describing a td or tf process around a sustainability problem. A necessary condition was that the paper described processes with an explicit naming of actors involved ( $\rightarrow$ "who") and their respective activities ( $\rightarrow$ "what"). This included articles elaborating on the roles of actors, as well as papers discussing participation concepts or programme evaluations. We focused on peerreviewed articles, as this approach allowed for the systematic identification of material and papers that had already been through a quality control process. Furthermore, we assumed that in these articles (due to their restricted length) the authors focused on activities they perceived as relevant. Due to notable differences in the search results (see Fig. 1), the database results from Scopus and Web of Science were combined. The following search terms were applied, restricted to literature published from 1945 up to September 2020:

\section{Scopus}

TITLE-ABS-KEY (transdisciplin*) AND TITLE-ABSKEY (sustainab* OR transformat* OR eco*) AND TITLE-ABS-KEY (Partner* OR practition* OR partne* OR stakeholder* OR decision* OR "agent" OR actor* OR role*) AND TITLE-ABS-KEY (Activit* OR codesign OR co-production OR collaborat* OR consultat* OR particip* OR involve* OR interact* OR task OR responsibil* OR function*) AND SRCTYPE(j)

\section{Web of Science}

(TS $=$ transdisciplin* AND TS $=$ (sustainab* OR transformat* OR eco*) AND TS=(Partner* OR practition* OR partne* OR stakeholder* OR decision* OR "agent" OR actor* OR role*) AND TS=(Activit* OR co-design OR co-production OR collaborat* OR consultat* OR particip* OR involve* OR interact* OR task OR responsib* OR function*)) AND LANGUAGE: (English) AND DOCUMENT TYPES: (Article) Indexes=SCIEXPANDED, SSCI, A\&HCI, ESCI Timespan=All years 
Fig. 1 PRISMA flow diagram 2009). The final step (quantitative synthesis) was not applied in our study (according to Moher et al.

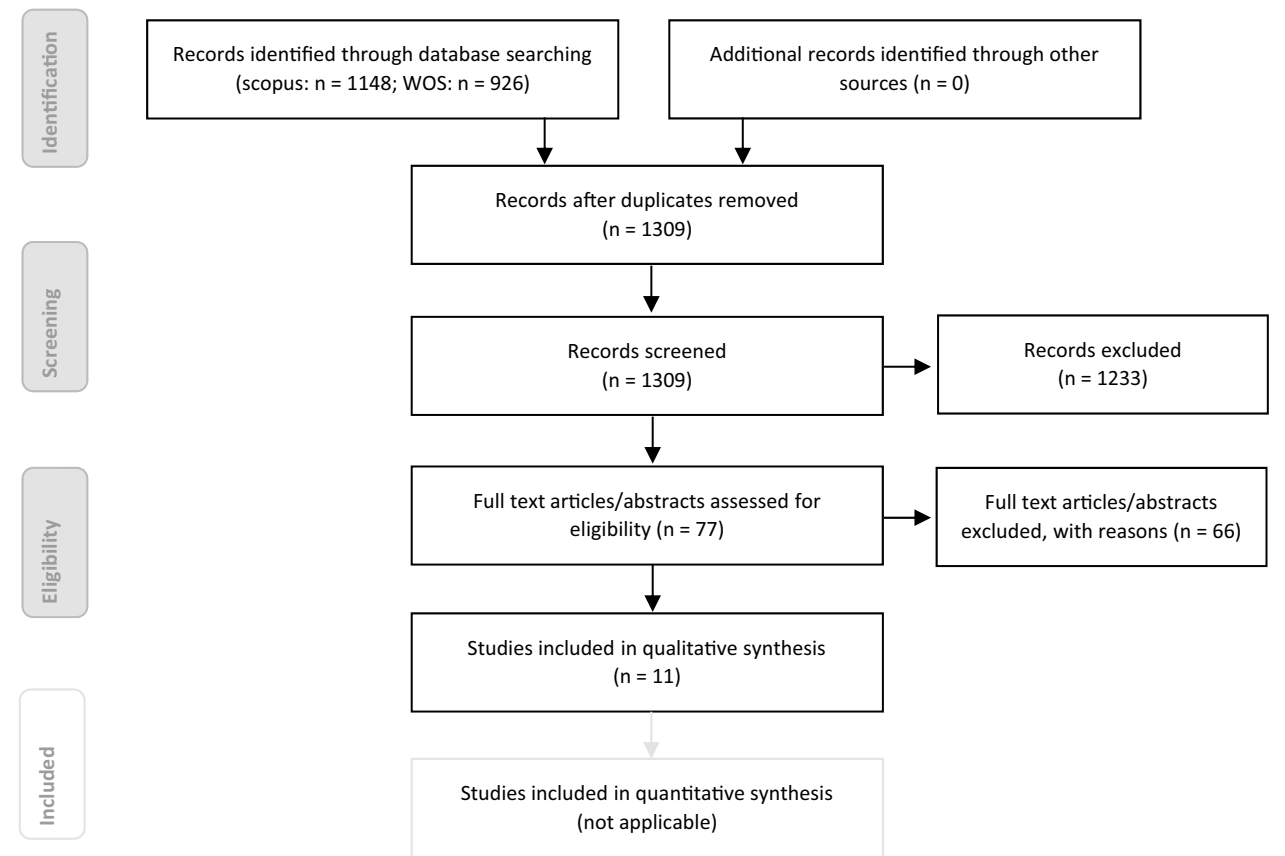

The data eventually used for the analysis included all articles dealing with the actor involvement/its intensity or describing participatory concepts, provided they contained information on actors ("who") and their activities ("what") in terms of research practice. Also included were papers describing the roles of actors involved in td and tf research processes focusing on the understanding of the roles outlined above. Excluded were all articles that did not encompass td processes with elements of interdisciplinarity and participation/collaboration to address a sustainability problem. Articles without explicit information on actors and their activities were also excluded. For a detailed overview on the criteria for exclusion, see supplementary material, $\mathrm{S} 1$.

By following the criteria outlined above, we identified 11 papers. The criterium of information on actors and their activities was the most decisive for narrowing down the papers for inclusion. Many papers elaborated on the selection, on a typology, or on the degree of involvement of nonscientific actors but did not report observed or attributed activities from specific cases. Equally, other papers analysed the perceptions, expectations, and motivations of nonscientific actors. Additional papers were excluded as they described roles without detailing the respective activities in certain cases, or were based only on a quantitative analysis.

The papers included encompass a wide range of activities and actors due to each paper's specific viewpoint and analytical framework, as well as the differences in the processes (see Table 2 and S 4). The representativeness of our study is limited by the small number of processes analysed, as well as their fundamental characteristics: all the articles are written from specific viewpoints to answer specific research descriptions of td and $t$ research processes which are not "neutral". The papers diverge furthermore both in terms of the problems under investigation and the geographical region. Although there is a focus on German-speaking regions, the processes took place in various regions of the world. Despite these limitations, our material serves best to derive a wide and relevant spectrum of potential roles, especially as it is based on a systematic literature review.

The differences between the analysed papers become visible in the varying number of codings of actor groups; some articles tend to focus on the activities of non-scientific actors, others on the activities of researchers (see Table 2). In total, attributed activities were found in three papers, whereas observed researcher activities were found in ten papers (only the paper by Felt et al. (2012) describes solely attributed activities). Nine papers describe observed practitioner activities and four papers also describe observed activities of the wider public. The number and main focus of coded activities also vary between the analysed papers (see S 5 and S 6). These differences can be traced back to the papers' different analytical frameworks, but also relate to the differences between the processes as outlined above (see Table 2). In terms of coding units, the number of observed researcher activities is the highest (see Table 2), which could be due to three papers explicitly dealing with researcher roles, whereas none focus on conceptual practitioner roles. Interestingly, the "wider public" code is almost always used together with the "practitioner" code (Table 3, column 8 and 9). questions, indicating that we analysed activities based on 
Table 2 Overview and characteristics of papers included in the analysis (short; for a long version, see S 4)

\begin{tabular}{|c|c|c|c|c|c|c|}
\hline $\begin{array}{l}1 \\
\text { Selected characteristics and number of codings for } \\
\text { each paper } \\
\text { Analysed paper }\end{array}$ & $\begin{array}{l}2 \\
\text { Country/ies of } \\
\text { the Process(es) }\end{array}$ & $\begin{array}{l}3 \\
\text { Number of } \\
\text { processes }\end{array}$ & $\begin{array}{l}4 \\
\text { Total activity } \\
\text { codes }\end{array}$ & $\begin{array}{l}5 \\
\mathrm{n} \text { codes } \\
\text { researcher }\end{array}$ & $\begin{array}{l}6 \\
\text { n codes } \\
\text { practitioner }\end{array}$ & $\begin{array}{l}7 \\
\text { n codes wider } \\
\text { public }\end{array}$ \\
\hline $\begin{array}{l}\text { Enengel, B.; Muhar, A. (2012): Co-production of } \\
\text { knowledge in transdisciplinary doctoral theses } \\
\text { on landscape development-An analysis of actor } \\
\text { roles and knowledge types in different research } \\
\text { phases. In: Landscape and Urban Planning, } \\
105(1-2), 106-117\end{array}$ & Austria & 4 & 11 & 4 & 6 & 1 \\
\hline $\begin{array}{l}\text { Felt, U.; Igelsböck, J.et al. (2012): Challenging } \\
\text { Participation in Sustainability Research. In: } \\
\text { International Journal of Deliberative Mecha- } \\
\text { nisms in Science, 1, 4-34 }\end{array}$ & Austria & Programme & 13 & $0[6]$ & $0[6]$ & $0[1]$ \\
\hline $\begin{array}{l}\text { Fritz, L.; Binder, C. R. (2020): Whose knowledge, } \\
\text { whose values? An empirical analysis of power } \\
\text { in transdisciplinary sustainability research. In: } \\
\text { European Journal of Futures Research, } 8(3)\end{array}$ & Germany & 5 & 34 & $14[2]$ & $15[3]$ & 0 \\
\hline $\begin{array}{l}\text { Hilger, A.; Rose, M. et al. (2018): Changing } \\
\text { faces-factors influencing the roles of researchers } \\
\text { in real-world laboratories. GAIA-Ecological } \\
\text { Perspectives for Science and Society, 27(2), } \\
\text { 138-145 }\end{array}$ & Germany & 3 & 8 & 8 & 0 & 0 \\
\hline $\begin{array}{l}\text { Klenk, N. L.; Meehan, K. (2017): Transdiscipli- } \\
\text { nary sustainability research beyond engagement } \\
\text { models. Toward adventures in relevance. Envi- } \\
\text { ronmental Science \& Policy, 78, 27-35 }\end{array}$ & $\begin{array}{c}\text { Latin America, } \\
\text { Caribbean }\end{array}$ & Programme & 10 & 3 & $1[5]$ & $0[1]$ \\
\hline $\begin{array}{l}\text { Lindsay, J.; Rogers, B. C et al. (2019): The role of } \\
\text { community champions in long-term sustainable } \\
\text { urban water planning. Water, 11(3), 1-14 }\end{array}$ & Australia & 1 & 28 & 8 & 19 & 1 \\
\hline $\begin{array}{l}\text { Pohl, C.; Rist, S. et al. (2010): Researchers' roles } \\
\text { in knowledge co-production. Experience from } \\
\text { sustainability research in Kenya, Switzerland, } \\
\text { Bolivia and Nepal. Science and Public Policy, } \\
\text { 37(4), 267-281 }\end{array}$ & $\begin{array}{l}\text { Kenya, Switzer- } \\
\text { land, Bolivia, } \\
\text { Nepal }\end{array}$ & 4 & 40 & 26 & 14 & 0 \\
\hline $\begin{array}{l}\text { Reed, M. G.; Abernethy, P. (2018): Facilitating } \\
\text { Co-Production of Transdisciplinary Knowledge } \\
\text { for Sustainability: Working with Canadian Bio- } \\
\text { sphere Reserve Practitioners 31(1) }\end{array}$ & Canada & 1 & 24 & 14 & 10 & 0 \\
\hline $\begin{array}{l}\text { Schmidt, L.; Hartberger, K. et al. (2018): } \\
\text { Stakeholder Involvement in Transdisciplinary } \\
\text { Research. Lessons from Three Projects on } \\
\text { Sustainable Land Management in a North-South } \\
\text { Setting. GAIA-Ecological Perspectives for Sci- } \\
\text { ence and Society, 27(3), 312-320 }\end{array}$ & $\begin{array}{l}\text { Madagas- } \\
\text { car, Brazil, } \\
\text { Angola/ } \\
\text { Botswana/ } \\
\text { Namibia }\end{array}$ & 3 & 36 & 18 & 18 & 0 \\
\hline $\begin{array}{l}\text { Stauffacher, M.; Flüeler, T. et al. (2008): Analytic } \\
\text { and Dynamic Approach to Collaboration. A } \\
\text { Transdisciplinary Case Study on Sustainable } \\
\text { Landscape Development in a Swiss Prealpine } \\
\text { Region. Systemic Practice and Action Research, } \\
\text { 21(6), 409-422 }\end{array}$ & Switzerland & 1 & 39 & 19 & 14 & 6 \\
\hline $\begin{array}{l}\text { Wittmayer, J. M.; Schäpke, N. (2014): Action, } \\
\text { research and participation. Roles of researchers } \\
\text { in sustainability transitions. Sustainability Sci- } \\
\text { ence, 9(4), 483-496 }\end{array}$ & The Netherlands & 1 & 30 & 26 & 3 & 1 \\
\hline Total & & & 273 & $140[8]$ & $100[14]$ & $9[2]$ \\
\hline
\end{tabular}

The table shows the country in which the tr/td research processes took place, the number of processes described in the papers, and the total number of activity codes (column 4). Column 5-7 contains the number of activity codes for different actor groups, with the number of codes for attributed activities in brackets 
Table 3 Overview of roles, clusters and subclusters of activities and their frequency

\begin{tabular}{|c|c|c|c|c|c|c|c|c|}
\hline 1 & 2 & 3 & 4 & 5 & 6 & 7 & 8 & 9 \\
\hline Roles & Activities & $\begin{array}{l}\mathrm{n} \text { docs } \\
\quad(\text { role })\end{array}$ & $\begin{array}{l}\text { (Sub)cluster } \\
\text { (act.) }\end{array}$ & n docs (act.) & $\begin{array}{c}\mathrm{n} \text { codes } \\
\text { (act.) }\end{array}$ & $\begin{array}{l}\mathrm{n} \text { docs } \\
\text { (res.) }\end{array}$ & $\begin{array}{l}\mathrm{n} \text { docs } \\
\text { (pract.) }\end{array}$ & $\begin{array}{l}\mathrm{n} \text { docs } \\
\quad \text { (publ.) }\end{array}$ \\
\hline \multirow[t]{13}{*}{ Choreographer } & & 9 & & & & & & \\
\hline & $\begin{array}{l}\text { Select and invite participants (to } \\
\text { take part in the process) }\end{array}$ & & a1 & 7 & 16 & 6 & 3 & 1 \\
\hline & $\begin{array}{l}\text { Generally: organise and structure } \\
\text { the process (and/or project) }\end{array}$ & & a1 & 5 & 9 & 5 & 3 & 0 \\
\hline & $\begin{array}{l}\text { Network with potentially relevant } \\
\text { actors }\end{array}$ & & e1 & 4 & 12 & 3 & 2 & 0 \\
\hline & $\begin{array}{l}\text { Review/discuss needs and expec- } \\
\text { tations for the process/project }\end{array}$ & & h1 & 5 & 8 & 3 & 3 & 0 \\
\hline & $\begin{array}{l}\text { Adjust the process design as a } \\
\text { response to process develop- } \\
\text { ments }\end{array}$ & & h1 & 5 & 7 & 5 & 0 & 0 \\
\hline & $\begin{array}{l}\text { Write observation protocols or } \\
\text { research diaries on the interac- } \\
\text { tion }\end{array}$ & & h1 & 3 & 4 & 3 & 0 & 0 \\
\hline & $\begin{array}{l}\text { Involve participants/community } \\
\text { in designing/developing the } \\
\text { process }\end{array}$ & & i2 & 4 & 8 & 4 & 1 & 0 \\
\hline & $\begin{array}{l}\text { (Potentially) End collaboration or } \\
\text { threaten to do so }\end{array}$ & & i2 & 2 & 6 & 0 & 2 & 0 \\
\hline & $\begin{array}{l}\text { Plan/develop the process or pro- } \\
\text { ject with practice partner }\end{array}$ & & i2 & 2 & 5 & 2 & 1 & 0 \\
\hline & $\begin{array}{l}\text { Establish working structures for } \\
\text { the project }\end{array}$ & & i2 & 2 & 2 & 2 & 0 & 0 \\
\hline & $\begin{array}{l}\text { Plan/develop the process or pro- } \\
\text { ject without practice partner }\end{array}$ & & i2 & 1 & 5 & 1 & 0 & 0 \\
\hline & $\begin{array}{l}\text { Negotiate the conditions of being } \\
\text { part of the process }\end{array}$ & & i2 & 1 & 5 & 1 & 1 & 0 \\
\hline \multirow[t]{13}{*}{ Facilitator } & & 9 & & & & & & \\
\hline & Moderate meetings or workshops & & $\mathrm{e} 2$ & 7 & 19 & 7 & 1 & 0 \\
\hline & $\begin{array}{l}\text { Initiate and facilitate learning } \\
\text { processes }\end{array}$ & & e2 & 5 & 10 & 5 & 1 & 0 \\
\hline & $\begin{array}{l}\text { Build trust and confidence about } \\
\text { the project and between actors }\end{array}$ & & e2 & 4 & 12 & 4 & 2 & 0 \\
\hline & $\begin{array}{l}\text { Balance different interests and } \\
\text { potential conflicts }\end{array}$ & & $\mathrm{e} 2$ & 4 & 9 & 4 & 1 & 0 \\
\hline & $\begin{array}{l}\text { Bridge cultural and language } \\
\text { differences }\end{array}$ & & $\mathrm{e} 2$ & 4 & 7 & 3 & 2 & 0 \\
\hline & $\begin{array}{l}\text { Encourage expressions of all } \\
\text { viewpoints }\end{array}$ & & e2 & 4 & 4 & 4 & 0 & 0 \\
\hline & $\begin{array}{l}\text { Consider and balance power } \\
\text { hierarchies and dynamics }\end{array}$ & & $\mathrm{e} 2$ & 3 & 9 & 3 & 0 & 0 \\
\hline & $\begin{array}{l}\text { (Aim to) Empower process par- } \\
\text { ticipants/community }\end{array}$ & & i6 & 4 & 7 & 4 & 1 & 0 \\
\hline & Organise meetings or workshops & & i6 & 3 & 4 & 3 & 0 & 0 \\
\hline & $\begin{array}{l}\text { Provide space deliberately for } \\
\text { critical reflection }\end{array}$ & & i6 & 3 & 4 & 3 & 0 & 0 \\
\hline & $\begin{array}{l}\text { Formulate future ambitions and } \\
\text { follow up activities }\end{array}$ & & i6 & 2 & 3 & 1 & 2 & 0 \\
\hline & $\begin{array}{l}\text { Generally: facilitate and encour- } \\
\text { age knowledge integration }\end{array}$ & & i6 & 2 & 2 & 2 & 0 & 0 \\
\hline
\end{tabular}


Table 3 (continued)

\begin{tabular}{|c|c|c|c|c|c|c|c|c|}
\hline 1 & 2 & 3 & 4 & 5 & 6 & 7 & 8 & 9 \\
\hline \multirow[t]{6}{*}{ Intermediary } & & 8 & & & & & & \\
\hline & $\begin{array}{l}\text { Mediate between different per- } \\
\text { spectives and viewpoints }\end{array}$ & & f1 & 6 & 14 & 6 & 1 & 0 \\
\hline & $\begin{array}{l}\text { Guide/apply integration methods/ } \\
\text { workshop techniques }\end{array}$ & & f1 & 5 & 14 & 5 & 0 & 0 \\
\hline & $\begin{array}{l}\text { (Aim to) Give affected or under- } \\
\text { represented people or groups } \\
\text { a voice }\end{array}$ & & f1 & 4 & 6 & 4 & 0 & 0 \\
\hline & $\begin{array}{l}\text { Make thought styles or different } \\
\text { perspectives explicit }\end{array}$ & & f1 & 3 & 11 & 3 & 1 & 0 \\
\hline & $\begin{array}{l}\text { (Aim to) Integrate different } \\
\text { thought styles }\end{array}$ & & f1 & 3 & 8 & 2 & 1 & 0 \\
\hline \multirow{4}{*}{$\begin{array}{l}\text { Knowledge Col- } \\
\text { lector }\end{array}$} & & 8 & & & & & & \\
\hline & $\begin{array}{l}\text { Collect data (e.g. interviews, } \\
\text { observations, surveys) }\end{array}$ & & $\mathrm{d} 2$ & 8 & 22 & 8 & 1 & 0 \\
\hline & $\begin{array}{l}\text { Document and present the } \\
\text { knowledge brought into the } \\
\text { process }\end{array}$ & & $\mathrm{d} 2$ & 6 & 15 & 6 & 1 & 0 \\
\hline & $\begin{array}{l}\text { Participatory observation of the } \\
\text { field and its developments }\end{array}$ & & $\mathrm{d} 2$ & 4 & 8 & 4 & 1 & 0 \\
\hline \multirow{14}{*}{$\begin{array}{l}\text { Knowledge Co- } \\
\text { Producer }\end{array}$} & & 8 & & & & & & \\
\hline & $\begin{array}{l}\text { Discuss (final) results and/or } \\
\text { derived recommendations }\end{array}$ & & c3 & 4 & 12 & 3 & 3 & 0 \\
\hline & $\begin{array}{l}\text { Contribute or discuss a suggested } \\
\text { solution or strategy }\end{array}$ & & $\mathrm{c} 3$ & 4 & 11 & 2 & 3 & 0 \\
\hline & $\begin{array}{l}\text { Select, discuss, or develop } \\
\text { research methods/instruments }\end{array}$ & & $\mathrm{c} 3$ & 3 & 5 & 2 & 2 & 0 \\
\hline & $\begin{array}{l}\text { Contribute own view/opinion/ } \\
\text { interpretation of the case/ } \\
\text { scenario }\end{array}$ & & i1 & 5 & 10 & 1 & 5 & 1 \\
\hline & $\begin{array}{l}\text { Be involved as a potentially } \\
\text { affected person/group }\end{array}$ & & i1 & 4 & 7 & 0 & 3 & 1 \\
\hline & $\begin{array}{l}\text { Agree on a common problem } \\
\text { focus/problem perception }\end{array}$ & & i1 & 4 & 8 & 2 & 4 & 1 \\
\hline & $\begin{array}{l}\text { Define or agree on process/ } \\
\text { research goals }\end{array}$ & & i1 & 4 & 5 & 3 & 3 & 0 \\
\hline & $\begin{array}{l}\text { Discuss and validate (prelimi- } \\
\text { nary) research results }\end{array}$ & & i1 & 2 & 9 & 2 & 2 & 1 \\
\hline & $\begin{array}{l}\text { Engage in a visioning process or } \\
\text { share a vision }\end{array}$ & & i1 & 2 & 9 & 1 & 2 & 0 \\
\hline & $\begin{array}{l}\text { Develop and bring ideas to the } \\
\text { process }\end{array}$ & & i1 & 2 & 6 & 1 & 1 & 0 \\
\hline & $\begin{array}{l}\text { Define or agree on a common } \\
\text { research question }\end{array}$ & & i1 & 2 & 4 & 2 & 2 & 0 \\
\hline & $\begin{array}{l}\text { Generally: contribute knowledge } \\
\text { (not further specified) }\end{array}$ & & i1 & 2 & 3 & 2 & 1 & 0 \\
\hline & $\begin{array}{l}\text { Generally: engage in knowledge } \\
\text { co-production processes }\end{array}$ & & i1 & 1 & 1 & 0 & 1 & 0 \\
\hline \multirow[t]{2}{*}{ Field Expert } & & 7 & & & & & & \\
\hline & $\begin{array}{l}\text { Contribute (local) context-spe- } \\
\text { cific knowledge on a specific } \\
\text { case }\end{array}$ & & b1 & 7 & 20 & 1 & 7 & 3 \\
\hline
\end{tabular}


Table 3 (continued)

\begin{tabular}{|c|c|c|c|c|c|c|c|c|}
\hline 1 & 2 & 3 & 4 & 5 & 6 & 7 & 8 & 9 \\
\hline & $\begin{array}{l}\text { Contribute experiential, tacit, or } \\
\text { traditional knowledge }\end{array}$ & & b1 & 4 & 9 & 0 & 4 & 1 \\
\hline & $\begin{array}{l}\text { Provide contacts/access to per- } \\
\text { sons in the field }\end{array}$ & & b1 & 4 & 7 & 0 & 4 & 0 \\
\hline & $\begin{array}{l}\text { Contribute strategic knowledge } \\
\text { (organisational, functional, } \\
\text { network) }\end{array}$ & & b1 & 3 & 8 & 0 & 3 & 1 \\
\hline \multirow[t]{3}{*}{ Data Supplier } & & 7 & & & & & & \\
\hline & $\begin{array}{l}\text { Respond to surveys or interviews } \\
\text { (be interviewed) }\end{array}$ & & $\mathrm{c} 1$ & 6 & 11 & 0 & 6 & 1 \\
\hline & $\begin{array}{l}\text { Provide information or data and } \\
\text { support data collection }\end{array}$ & & $\mathrm{c} 1$ & 2 & 3 & 0 & 2 & 1 \\
\hline \multirow{4}{*}{$\begin{array}{l}\text { Results Dissemina- } \\
\text { tor }\end{array}$} & & 7 & & & & & & \\
\hline & $\begin{array}{l}\text { Translate and disseminate results } \\
\text { and raise awareness }\end{array}$ & & $\mathrm{i} 4$ & 5 & 12 & 4 & 2 & 0 \\
\hline & $\begin{array}{l}\text { Produce policy-relevant knowl- } \\
\text { edge, recommendations, or } \\
\text { tools }\end{array}$ & & $\mathrm{i} 4$ & 4 & 5 & 4 & 1 & 0 \\
\hline & $\begin{array}{l}\text { Participate in writing popular } \\
\text { science articles or reports (PR) }\end{array}$ & & $\mathrm{i} 4$ & 2 & 3 & 2 & 0 & 0 \\
\hline \multirow[t]{3}{*}{ Communicator } & & 7 & & & & & & \\
\hline & $\begin{array}{l}\text { Engage in informal communica- } \\
\text { tion }\end{array}$ & & $\mathrm{d} 1$ & 6 & 9 & 5 & 2 & 0 \\
\hline & Engage in formal communication & & $\mathrm{d} 1$ & 6 & 7 & 6 & 2 & 0 \\
\hline \multirow[t]{3}{*}{ Practice Expert } & & 6 & & & & & & \\
\hline & $\begin{array}{l}\text { Contribute expertise and applica- } \\
\text { tion-oriented knowledge }\end{array}$ & & i7 & 5 & 7 & 2 & 4 & 0 \\
\hline & $\begin{array}{l}\text { Engage in or support an } \\
\text { experiment/a real-life change }\end{array}$ & & i7 & 4 & 7 & 3 & 1 & 0 \\
\hline \multirow[t]{4}{*}{ Scientific Analyst } & & 5 & & & & & & \\
\hline & $\begin{array}{l}\text { Contribute scientific knowledge } \\
\text { (based on analysis) }\end{array}$ & & $\mathrm{f} 2$ & 5 & 10 & 4 & 0 & 0 \\
\hline & $\begin{array}{l}\text { Evaluate the process, project, or } \\
\text { intervention }\end{array}$ & & $\mathrm{f} 2$ & 3 & 9 & 3 & 2 & 1 \\
\hline & $\begin{array}{l}\text { Carry out a system or actor } \\
\text { analysis }\end{array}$ & & $\mathrm{f} 2$ & 3 & 8 & 3 & 0 & 0 \\
\hline \multirow{5}{*}{$\begin{array}{l}\text { Self-Reflexive Par- } \\
\text { ticipant }\end{array}$} & & 5 & & & & & & \\
\hline & $\begin{array}{l}\text { Generally: engage in a process of } \\
\text { (self-)reflection }\end{array}$ & & i5 & 5 & 9 & 4 & 2 & 0 \\
\hline & $\begin{array}{l}\text { Self-reflect upon own normative } \\
\text { orientation }\end{array}$ & & i5 & 2 & 3 & 2 & 0 & 0 \\
\hline & $\begin{array}{l}\text { Self-reflect upon internal and } \\
\text { external power dynamics }\end{array}$ & & i5 & 2 & 2 & 2 & 0 & 0 \\
\hline & $\begin{array}{l}\text { Raise/thematise roles and self- } \\
\text { awareness }\end{array}$ & & i5 & 1 & 3 & 1 & 0 & 0 \\
\hline \multirow[t]{3}{*}{ Coordinator } & & 4 & & & & & & \\
\hline & $\begin{array}{l}\text { Lead the tr/td process or case } \\
\text { study }\end{array}$ & & $\mathrm{f} 3$ & 4 & 9 & 4 & 1 & 0 \\
\hline & $\begin{array}{l}\text { Be the contact person for the } \\
\text { project (coordinator) }\end{array}$ & & $\mathrm{f} 3$ & 2 & 3 & 2 & 0 & 0 \\
\hline
\end{tabular}


Table 3 (continued)

\begin{tabular}{|c|c|c|c|c|c|c|c|c|}
\hline 1 & 2 & 3 & 4 & 5 & 6 & 7 & 8 & 9 \\
\hline \multirow[t]{3}{*}{ Application Expert } & & 4 & & & & & & \\
\hline & $\begin{array}{l}\text { Test and adapt the project results } \\
\text { in the application context }\end{array}$ & & $\mathrm{c} 2$ & 4 & 5 & 0 & 4 & 0 \\
\hline & $\begin{array}{l}\text { Apply process results or poten- } \\
\text { tially introduce them into the } \\
\text { decision-making process }\end{array}$ & & $\mathrm{c} 2$ & 3 & 8 & 0 & 3 & 0 \\
\hline \multirow[t]{4}{*}{ Troublemaker } & & 3 & & & & & & \\
\hline & $\begin{array}{l}\text { Maintain previous relationships } \\
\text { and conflicts with others }\end{array}$ & & i3 & 2 & 2 & 0 & 2 & 0 \\
\hline & $\begin{array}{l}\text { Negotiate and contest rules of } \\
\text { interaction }\end{array}$ & & i3 & 1 & 2 & 1 & 1 & 0 \\
\hline & $\begin{array}{l}\text { Obstruct the supply, use, or } \\
\text { extraction of data from the field }\end{array}$ & & i3 & 1 & 3 & 1 & 1 & 0 \\
\hline
\end{tabular}

The table shows the 15 roles (column 1), consisting of (a set of) coded activities (column 2). Column 3 contains the number of documents (weighted) with one or more activities for the respective role and thus provides information about the frequency of the role. The small letters in column 4 show the eight clusters from the hierarchical cluster analysis, with the numbers showing the subclusters. The letters in column 4 match the clusters in Fig. 3 as follows: $\mathrm{a}=$ orange, $\mathrm{b}=$ green, $\mathrm{c}=$ mauve, $\mathrm{d}=$ blue $\&$ purple, $\mathrm{e}=$ red, $\mathrm{f}=$ yellow, h\&i $=$ turquoise. Column 5 shows the number of documents (weighted) containing each activity, and column 6 shows the total number of times each activity occurs. Columns 7-9 show the number of documents in which the activities of the respective actor/actor group were observed

\section{Analytical steps}

To analyse the selected papers, we used the software MAXQDA 2020 (VERBI Software 2019). Our aim was to analyse the joint occurrence and the proximity of activities observed in the processes, as reported in the papers. For an overview of our analytical steps, see Fig. 2.

In step one, we coded the parts in the papers containing information on one or more activities undertaken by an actor. These coding units had to be in the papers' description of the cases and the results section; although the discussion section might also have contained this type of information, it was not included for consideration as it was generally on a more abstract level. The coding system consisted of codes on the papers' context, role conceptions, actors, and activities (for an overview, see $S$ 2). To ensure robust coding of sound quality, two authors intensively discussed the coding system in an iterative way throughout the analysis. Unclear coding units were marked and subsequently cleared through joint discussion. After all the papers were coded once and the coding system was fully developed, all the papers were re-coded.

The activity codes were as concrete and detailed as possible, with the aim of capturing the nuances of the activities and gaining a precise picture of potential roles. Accordingly, in vivo coding was mainly used, which resulted in 72 activity codes (see Table 3, column 2) and 549 activity codings. To capture all activities relating to a code unit, multiple activity codes were coded per coding unit where necessary. Activities were coded if they were explicitly named; if not, they were not included for consideration. For example, the activity of "engaging in informal communication" was probably carried out in almost all cases, but it was only coded if it was specified. To avoid interpretations, vague information about activities was classified under deliberately less precise codes, marked with "generally". Activities were also only coded when the performing actor was clear and explicit; sections including diverse activities undertaken by more than one actor that were not jointly performed were split up (for an example, see $\mathrm{S} 3$ ).

\section{Analytical Steps}

1) Coding the material (using activity and actor codes, as well as conceptual roles if applicable)

2) Descriptive analysis (paper descriptions, distribution of codes, role conceptions)

3) Cluster analysis (by means of the code map in MAXQDA, based on a hierarchical cluster analysis)

4) Forming the subcluster (based on coherence between the activities)

5) Merging the subcluster to roles (based on similarity between the activities and the actor groups reported performing the activities)

Fig. 2 Analytical steps of the analysis 
Each coding unit was parallel coded with an actor code in order to match the coded activities to an actor/actor group. The "non-scientific actor" group was split into the actor code of "practitioner" and "wider public" to be as precise as possible and to help identify different potential roles. The third actor code is "researcher".

Furthermore, we differentiated between activities that were empirically observed in the papers (e.g. in process descriptions) and activities that were attributed to the actor by the actor him/herself or by others. This dimension, "observation vs. attribution", was merged with the dimension of "actor group", which differentiates between researcher, practitioner, and the wider public. This resulted in six actor groups in total, with codes such as "observed: wider public". The actor codes for observed activities were used 249 times, whereas actor codes for attributed activities were only used 24 times. The actor codes were usually used once per code unit; exceptions were made when all the activities were carried out by two or more actor groups (e.g. the activity "collaboratively plan and develop the process or project").

Three papers specifically described researchers' roles (Hilger et al. 2018; Pohl et al. 2010; Wittmayer and Schäpke 2014), and the paper by Reed et al. (2018) dealt with the role of a 'third actor', i.e. the boundary manager (see Sect. 2). In these papers, we also coded these previously defined role conceptions to examine how they relate to actors' activities.

In a second step, we analysed the papers' characteristics and context, the number and distribution of codes within the papers, and coherence with the previously defined role conceptions (see S 7).

In step three, we analysed the joint occurrence of the 72 activities by using the code map in MAXQDA, which is based on a hierarchical cluster analysis (VERBI Software 2020, p. 383). To identify the roles played by actors, in this analysis we only considered those activities that the authors of the analysed papers actually observed. Activities that were described in the papers as attributed to certain actors were not considered. Eight clusters were identified by applying a classic multi-dimensional scaling method (VERBI Software 2020, p. 383). In the hierarchical cluster analysis, a similarity matrix is converted into a distance matrix by subtracting the similarity of two codes from the maximum possible similarity in each cell. Thus, the more frequently the activities were coded together (denoting their similarity to each other), the closer they are on the map. However, due to this two-dimensional procedure, some codes may be closer on the code map than in reality. Due to the differences in the analysed material, in the cluster analysis the joint occurrence of activities was considered per paper as opposed to reflecting the absolute number of overlapping activity codes.

In step four, we formed a coherent set of 21 subclusters from the eight identified clusters (see Table 3, column 4). The code map (see Fig. 3) shows three clusters, each with coherent activities ( $h=$ turquoise, $a=$ orange, and $b=$ green). Two other, rather similar, clusters ( $\mathrm{d}=$ blue, lila and $\mathrm{e}=\mathrm{red}$ ) were differentiated into two subclusters each, whereas the clusters $\mathrm{c}$ (=mauve) and $\mathrm{f}$ (=yellow) were divided into three coherent subclusters. From the clumsy turquoise cluster, which included 33 activities, we formed seven coherent subclusters. It becomes apparent in step four that the decision to use a detailed activity coding system could be queried, as not all the articles described the activities in the same detail, and it is unclear whether the papers' authors intentionally used specific wording. The fine-grained activity codes could explain why some clusters include similar activities (for example, the four subclusters of the Knowledge Co-Producer role) or account for the differences between the mediating and empowering subclusters of the Facilitator role. The application of the actor code could also be criticised for potentially creating misunderstandings: although the code itself is used correctly, it could result in an imbalanced picture as several activities could be undertaken by different individual actors under the same actor code.

In step five, we summarised the 21 subclusters into a coherent set of 15 roles. In the process, we considered the similarity between the activities of the respective subclusters, as well as the similarity of the actor group performing the respective activities (see Table 3, column 7-9). In steps 3 to 5, each activity code was assigned to only one subcluster or role respectively; i.e. each activity could be part of only one role. We developed the terms based on the clustered activity bundles. The selection of suitable terms was furthermore informed by the usage of terms for roles described in the literature.

\section{Results}

In the following, we describe the 15 roles identified from eight clusters of 72 activities (see Fig. 3 ) and 21 subclusters (see Table 4, column 4), based only on the coded observed activities. We arrange the roles according to their relation to each other in a code map, applying the VERBI Software (2019) (Fig. 4). For the sake of a simple and clear overview, we also arranged the roles according to the four realms of activities: FIELD, ACADEMIA, BOUNDARY MANAGEMENT and CO-PRODUCTION (Fig. 5, own illustration). We enrich our description of the identified roles based on observed activities with the analysis of attributed activities.

We arrange the roles relating to activities that naturally originate in the field into the activity realm 'FIELD'. According to our analysis, these roles were usually adopted by non-scientific actors. Other roles are typically found in the activity realm of 'ACADEMIA' and were almost always adopted by scientific actors. A third group of roles, in the 


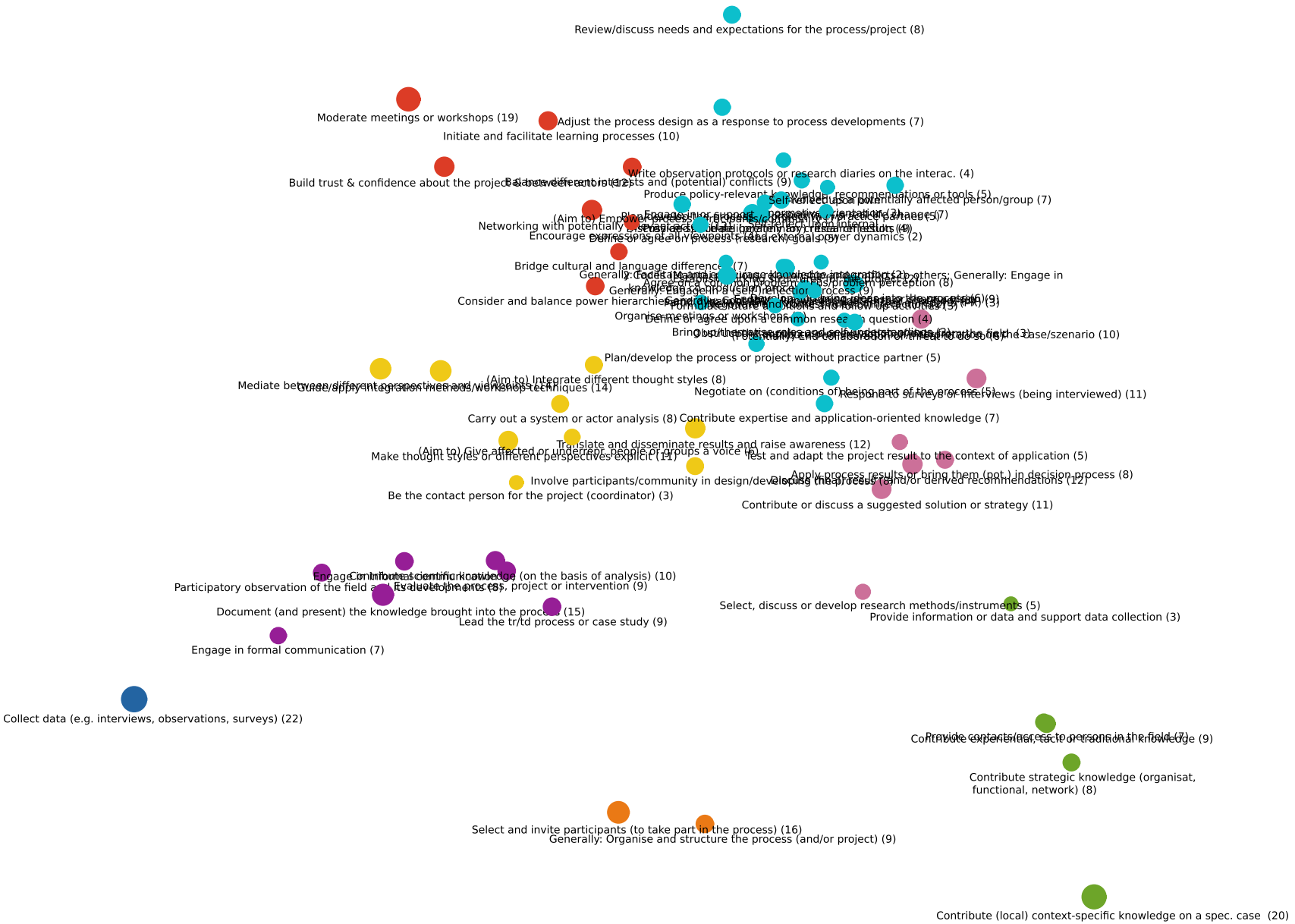

Fig. 3 Eight clusters of all observed activities. Dot size is in relation to the code frequency, number of coding units in brackets, weighted per document. Own data, analysed and illustrated with VERBI Software (2019)

realm of KNOWLEDGE CO-PRODUCTION, comprised activities within the process of knowledge co-production; consequently, they were adopted by researchers and nonscientific actors alike. Furthermore, roles in the realm of BOUNDARY MANAGEMENT were often, but not exclusively, adopted by researchers.

\section{Field}

The following three roles are almost exclusively undertaken by practitioners or the wider public.

The role of the Data Supplier includes activities where practitioners and the wider public take part in interviews, provide information, or support the researchers in their data collection. The designation refers to a similar role identified by Felt et al. (2012, p. 16).

The activities within the role of the Field Expert are usually undertaken by practitioners and the wider public. This role comprises the contribution of experiential, tacit, or traditional knowledge, as well as strategic knowledge or contacts to persons in the field. Specifically, the activity of contributing context-specific knowledge (often local) was evident in seven out of ten papers; this is also one of the main activities undertaken by the wider public. In addition to the perspective on observed activities, two articles also attribute these activities to practitioners.

The role of the Application Expert is to use the process results by applying them or potentially introducing them into the decision-making processes. This role is not only observed; three papers also attributed these activities to practitioners.

\section{Academia}

The role of the Scientific Analyst is named after the similar role of the "reflective scientist" as described by Pohl et al. (2010). It comprises research activities, such as the contribution of scientific knowledge or the preparation of a systems analysis. This role is only present in five of the analysed papers; three of which focus on the roles of 
Fig. 4 Code map showing the 15 roles, reflecting their similarity to each other. Dot size represents the number of coded activities (per document) that belong to the respective role. Own data, analysed with VERBI Software (2019)

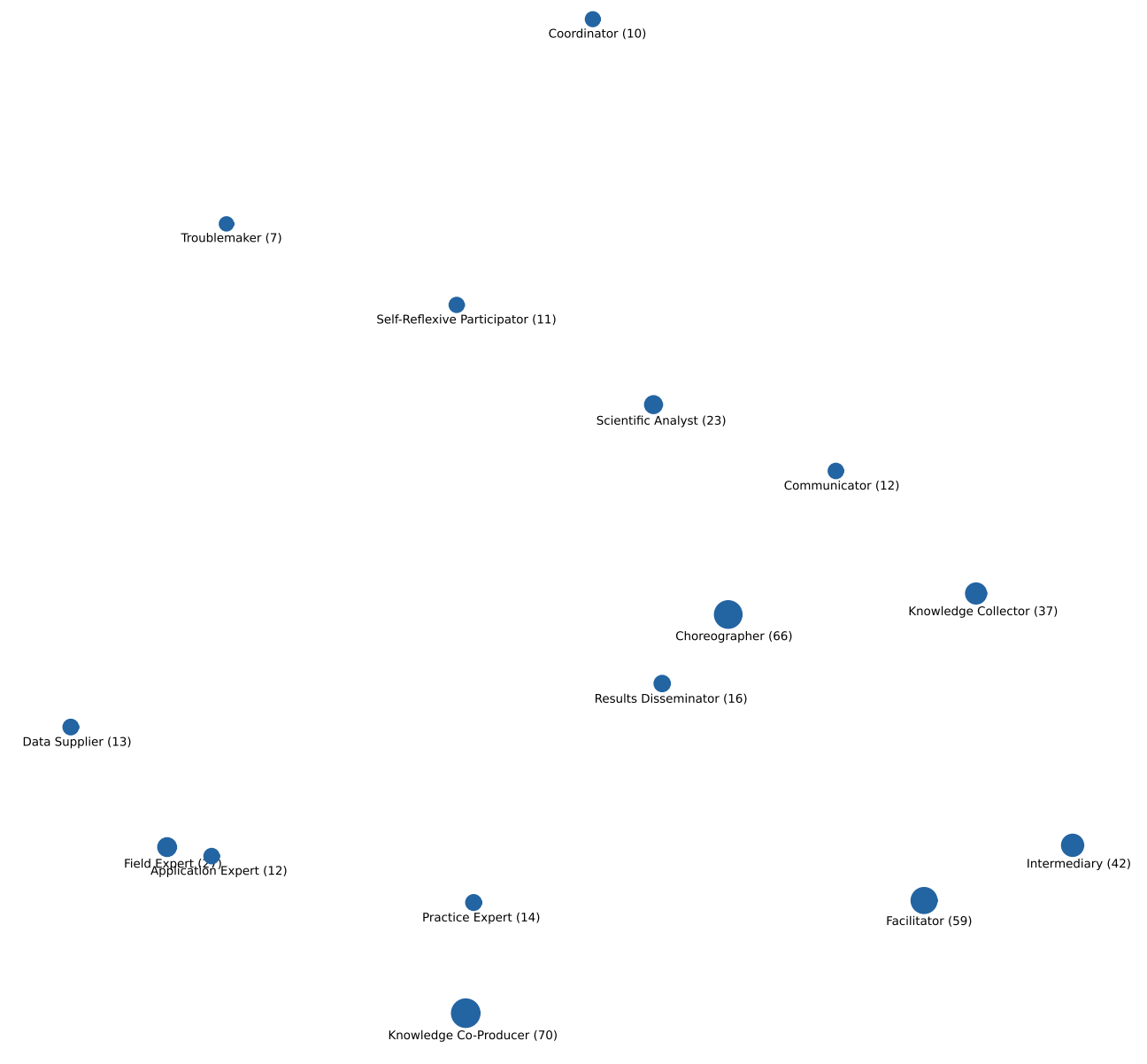

researchers. Nevertheless, this does not mean that the role is less important, as the focus of the papers included in our analysis is on the process itself rather than on the research activities.

The Knowledge Collector role comprises "classical" research activities, such as the collection of data, as well as activities related to participatory research. These include the observation of the field and activities in the realm of knowledge management, such as documenting and ultimately presenting the knowledge created by the process.

The roles of the Scientific Analyst and the Knowledge Collector are primarily adopted by researchers, but in two papers the activities of the Knowledge Collector are also undertaken by a practitioner.

\section{Knowledge co-production}

A number of roles explicitly comprise activities within the knowledge co-production process. Those roles are adopted by both researchers and non-scientific actors.

The role of the Knowledge Co-Producer includes four subclusters describing active involvement in the knowledge co-production process (see Table 4). It covers the agreement on a common problem focus or problem perception, as well as on the goals of the $\mathrm{td}$ and $\mathrm{tf}$ research processes and a joint research question. These activities are undertaken by both types of actors in a similar number of papers. The role also includes activities such as sharing ideas or a vision, contributing opinions or discussing preliminary and/or final research results.

The process of knowledge co-production may also involve certain negative aspects, such as dysfunctional social group dynamics, disagreements due to diverging interests and/or personal sensitivities. Three papers describe such activities and note that in certain cases actors fail to overcome challenging relationships and conflicts, or they actually obstruct the supply, use, or extraction of data from the field. We condensed those activities into the role of the Troublemaker. Strictly speaking, this role is not solely found within the coproduction process; for example, it might also be observed as a role close to the Data Supplier or the Field Expert.

The role of the Self-Reflexive Participant comprises selfreflection upon the actor's own normative orientation or internal and external power dynamics. It also serves to make roles and self-awareness a subject of discussion. Although it refers to the knowledge co-production process and to the process development, in the analysed material it is observed as an activity mainly undertaken by researchers. However, 


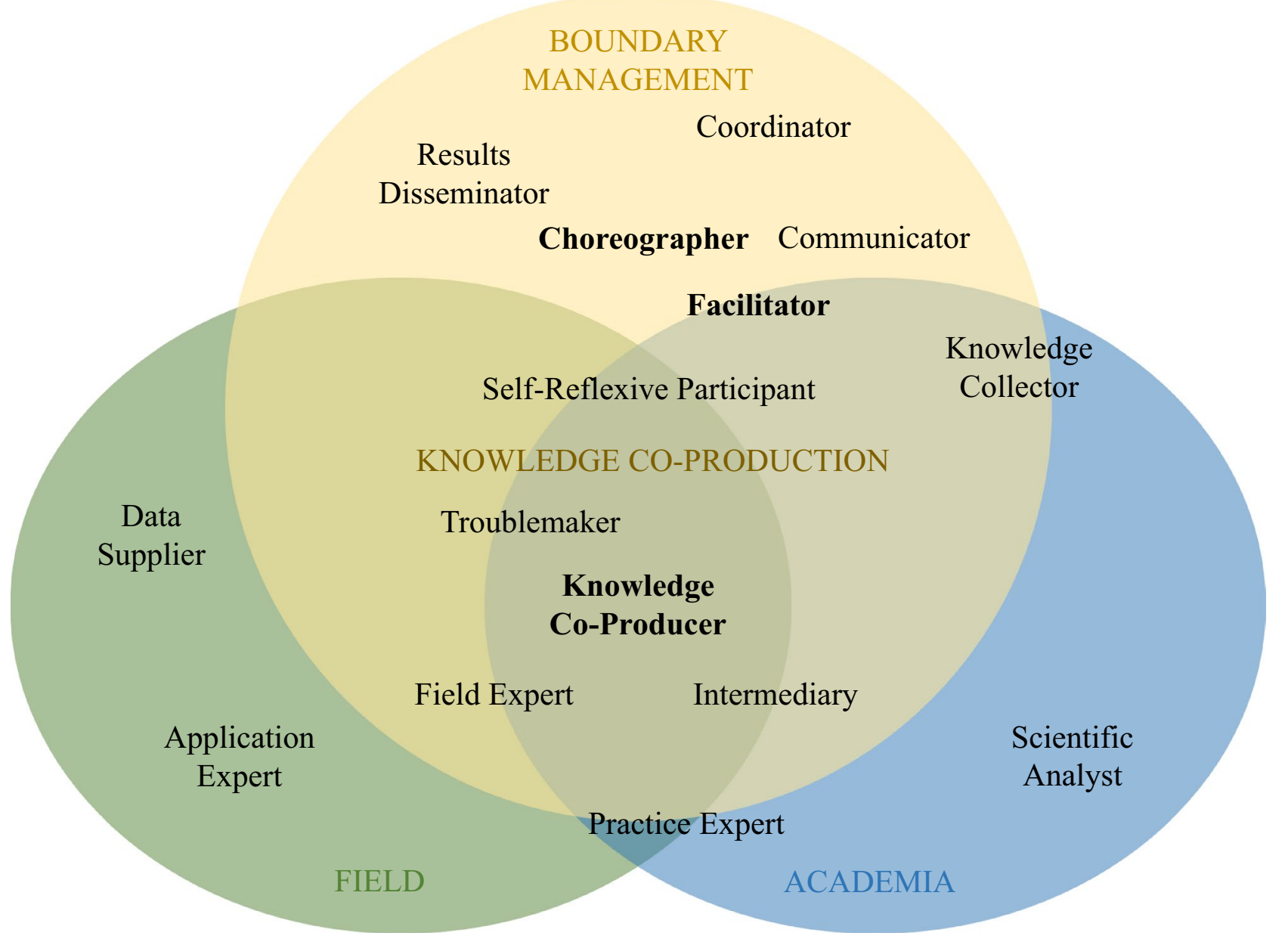

Fig. 5 Overview of the 15 identified roles, arranged in four activity realms. The FIELD (green) describes activities relating to expertise provided on the problem under investigation and the application of respective solutions, with roles primarily adopted by non-scientific actors. In contrast, the roles located in the realm of ACADEMIA (blue) involve research activities and tend to be adopted by research- ers. The BOUNDARY MANAGEMENT realm (yellow) includes activities required for establishing the processes of KNOWLEDGE CO-PRODUCTION; these take place in all the overlapping areas but especially where all three areas overlap. Roles highlighted in bold consist of more than one subcluster. (Source: own)

\section{Boundary management}

The roles of the Coordinator, the Choreographer, and to some extent the Facilitator are about organizational aspects of the td and tf research process, whereas the role of the Communicator, the Results Disseminator, and to a lesser extent the Facilitator are about the communicative level of the interaction. Although these are not per se scientific activities, they are often - but not exclusively — undertaken by researchers. One reason for this could be that current funding schemes mainly support research institutions; consequently, researchers tend to initiate the process and are (at least at the beginning) responsible for its development. Another reason could stem from the material analysed; three out of eleven papers deal with the roles of researchers, but 
none with the conceptual roles of practitioners or the wider public.

The Coordinator leads the process and is the main point of contact. This role tends to be carried out by researchers, but is also observed as a practitioner activity in the context of co-leadership in the paper described by Stauffacher et al. (2008, p. 412).

The role of the Choreographer includes four subclusters. It comprises activities such as "setting the stage", organising and structuring the process, and selecting and inviting participants. Those activities were generally observed as undertaken by researchers, but in three cases the practitioner was in charge of these activities. Two articles also attributed these activities to researchers. The Choreographer is also responsible for the joint development of the interaction process, which is by definition carried out by researchers and non-scientific actors. The role also comprises development and responsive process management, which includes writing observation protocols about the interactions. In addition to this activity-mainly undertaken by researchers - the role comprises reviewing and discussing the needs and expectations of the process/project. This specific aspect is undertaken by both types of actors.

The role of the Communicator comprises formal and informal communication; this is undertaken mainly by researchers, but at least two papers also mentioned it as a practitioner activity.

The role of the Results Disseminator is more frequently adopted by researchers, but only marginally. Translating and disseminating results and raising awareness were observed to be undertaken by practitioners; these activities were also attributed to practitioners in three documents. This role also includes the production of policy-relevant knowledge, recommendations, or tools, and the writing of popular scientific articles or reports.

The role of the Facilitator is formed from two subclusters; one with activities focusing on mediation and the other with activities focusing on empowerment. It comprises activities such as organising and moderating meetings and workshops, but combines also mediating activities (such as balancing different interests or encouraging the expression of many viewpoints) and empowerment activities (such as aiming to empower process participants, i.e. the community and consciously providing space for critical reflection). In the analysed papers, this role is mainly adopted by researchers, but on occasion activities belonging to this role are undertaken by practitioners.

\section{Discussion: beyond the duality of practitioner and researcher}

The aim of this paper was to disentangle the "gordian knot" (Klenk and Meehan 2017, p. 32) of the roles of actors involved in td and tf research processes in the context of sustainability science. By undertaking a systematic literature review and carrying out a fine-grained analysis of real td and tf research processes, we considered the breadth of activities involved in those processes and derived a wide spectrum of potential roles. With this work, we aim to facilitate transparency in practice: we specifically address the level of the individual in the process, as clarity about the roles played by actors allows for thorough expectation management, especially in terms of the activities that non-scientific partners are expected to undertake.

Based on the analysis of eleven papers on td and tf research processes with detailed descriptions of one or more processes, we identified four basic activity realms in which roles are observed. These realms are the FIELD, ACADEMIA, BOUNDARY MANAGEMENT and the COPRODUCTION PROCESS. The identified roles also link to previous research, as some of the roles described in our paper are similar to previously defined researcher roles. The roles of the Data Supplier, the Field Expert and the Application Expert are adopted by actors with close relationships to the field of the problem under investigation. In the context of ethnographic interactions, Dellwing and Prus (2012, p. 94) describe the challenges of access to the field: if this access is perceived as a service, it is highly likely that the actors will expect a service in return (Dellwing and Prus 2012, p. 94). This should be considered when planning a collaboration, especially when non-scientific actors exclusively adopt one of these roles in the realm of the FIELD and, therefore, neither participate in the knowledge co-production process nor gain a service in return. Furthermore, Felt et al. (2012, pp. 16-17) highlight that field access is a powerful position, as it enables the researchers' interaction with 'the field' to be controlled. This aspect is crucial when considering the role of the Data Supplier, who could influence the whole process by controlling access to the field. The role of the Scientific Analyst is similar to the "reflective scientist" as described by Pohl et al. (2010) and used by other authors (Bulten et al. 2021; Hilger et al. 2018; Horlings et al. 2020; Sarkki et al. 2013; Wittmayer and Schäpke 2014). This role and the Knowledge Collector are primarily adopted by scientific actors, which reflects the view that researchers are seen as "experts for validated, method-, theory-, and (partly) evidence-based descriptions" (Scholz 2020, p. 246).

Certain roles are also carried out within the actual coproduction process; these are primarily the Knowledge Co-Producer, the Practice Expert, and the Troublemaker. Some roles serve to enable this co-production process; these include the Coordinator, the Choreographer, and-to some extent - the Facilitator, and concern the "social-organizational level of integration in TD" (Jahn et al. 2012, p. 7). In contrast, the Communicator, the Results Disseminator, and - to a lesser extent - the Facilitator focus on the communicative level of integration. The role of the Intermediary 
addresses the "epistemic level of integration" (Jahn et al. 2012, p. 7). Pohl et al. (2010) describe this role, which was further developed as the "knowledge broker" by Wittmayer and Schäpke (2014). The role of the Facilitator is similar to the role of the "facilitator" as previously discussed (Pohl et al. 2010), but goes beyond that definition as it also includes mediating and empowerment activities. Together, these roles cover many activities listed in the discussions on "boundary management" or "third actor" (Cash et al. 2003, pp. 8087-8088). The extent and number of those roles within the realm of BOUNDARY MANAGEMENT demonstrate the importance of thorough process design using suitable methods and the effort required to achieve this (or, arguably, the attention paid to these activities in the analysed papers). The defined roles in this realm emphasise the arguments surrounding the need for boundary management (Cash et al. 2003); whether these activities should be undertaken by researchers, other actors, or specific institutions is a matter of debate.

In general, a greater number of roles were adopted by researchers than by the non-scientific partners. This is notable as many of the roles do not require a scientific education. One reason for this could be that researchers are often the initiators of the process and are responsible for its success (due to the terms of the funding). Therefore, they adopt a variety of roles to 'plug the gaps' in the process (e.g. highlighted by Stoecker 1999). In contrast, non-scientific actors often face the expectation of adopting the roles that are assigned to them externally (Felt et al. 2012; Klenk and Meehan 2017). By providing an overview of the potential roles involved in actual td and tf research process, we aim to contribute to clarity of research practice and help to reduce both these tendencies.

Although they might not all be present in all td and $\mathrm{tf}$ research processes, the heterogeneity of the identified roles shows that the duality of "researchers" interacting with "practitioners" is an oversimplified view of the process. More precisely, our analysis indicates that a diverse range of non-scientific and scientific actors perform both different and similar activities in td and tf research processes. Our intention was to look beyond the implicit expectations used to assign certain activities to certain actors, as prevalent in the previous literature. Instead of maintaining this narrow view of actors with a certain scope of activities, our work offers a way of reflecting with an open mind about the necessary and potential activities and roles.

This is particularly helpful when planning a collaboration and putting together a capable team, as it provides a framework for considering the activities that are already covered and the potential activities that may be required. In addition, when considering the different roles in planning or adapting a process, it is possible to divide and allocate responsibilities; for example, between (inter) disciplinary research (e.g. in the role of the Scientific Analyst) and activities within the knowledge integration process (e.g. in the roles of the Intermediary or Facilitator). By defining roles, researchers are also relieved from performing all the roles assumed necessary to guarantee a sound research process themselves. For non-scientific actors, our overview contributes to expectation management, as it provides initial descriptions of the potential roles non-scientific actors might undertake. This is pertinent when setting up a process, as the roles (consisting of a bundle of activities) offer precise descriptions of potential activities and, consequently, create awareness of likely expectations. By making the expectations of role performance more transparent in this way, our work could contribute to reducing or preventing role conflicts.

Furthermore, our differentiated view of the roles of actors also enables conflicts to be anticipated by highlighting potential difficulties contained within certain roles; for example, the Knowledge Co-Producer could withdraw from the process (Fritz and Binder 2020, p. 16) or the Field Expert might expect a service in return for their work (Dellwing and Prus 2012, p. 94) or "usable" research results. In this way, our work also illustrates that the roles in a td or tf research process are heterogeneous and interdependent on each other in several ways. Consequently, these diverse roles help to characterise the social relationships of the actors involved and whether "on eye-level" communication is feasible (Schauppenlehner-Kloyber and Penker 2015, p. 70).

Our paper also complements the discourse on participation and collaboration within td and tf research processes. When combined with the literature on td and tf process schemes, e.g. by Lang et al. (2012), Scholz and Steiner (2015a, b) and Wanner et al. (2018), our overview of roles may enhance clarity on who to involve and why (to ensure certain roles are covered in the process), when to involve the actor (in what process steps) and how frequently and intensely to involve the actor (referring to the intensity of participation or collaboration). These types of sound decisions (about who to involve, when, and how) enable nonscientific and scientific actors to be invited specifically to collaborate or participate. Such an approach is likely to be more successful than a participatory process involving a vaguely defined group of actors with diffuse interests.

\section{Conclusion}

$\mathrm{Td}$ and tf research processes are often new for non-scientific actors and are characterised as "research borderland" (Felt et al. 2013, p. 522) for scientific actors. This creates diverse expectations and uncertainties, as well as competing demands (Hilger and Keil 2021). In such situations, clarity about roles can provide the actors in the field with a 
“vocabulary” (Wittmayer and Schäpke 2014, p. 493) which could reduce uncertainty, enhance the process of role-taking, and enable confident role-making.

For this purpose, we identified 15 roles undertaken by actors involved in td and tf research processes. Our analysis was based on a systematic literature review of eleven papers. We aimed to draw as realistic a picture as possible by identifying roles based on 549 activity codings observed in td and tf research processes. Using a hierarchical cluster analysis, we analysed the joint occurrence of activities and the actor group(s) who primarily undertook these activities.

Studies to date have generally taken as their starting point certain groups of actors (researchers in particular) and then attempted to identify the roles and related activities they perform. We approached this from the opposite perspective: first we coded the activities observed in td and tf research processes and clustered them into roles, and then we identified who performs these roles.

In this way, we not only gathered insights into the roles primarily adopted by non-scientific actors, but also provided a more nuanced and complete picture of the roles played by all the actors involved. The heterogeneity of the roles raises questions about the prevalent perspective focusing on the duality of "practitioners" and "researchers" interacting in td and tf research processes. We advise actors who plan, implement, or analyse td and tf research processes to consider all the roles from a more unbiased and contextsensitive point of view. While certain roles seem to be necessary for a fruitful td or tf research process, the question of who adopts them should not be dominated by affiliations to certain pre-established actor groups. Even though we identified some plausible patterns of links between certain actor groups and roles in real-world td and tr research processes reported in the literature, individual actors should not be pigeon-holed by expectations implied by membership of a particular actor group. Instead, the definition of these roles and their related activities can help to reflect on the different competences of the individual actors involved and the tasks they should perform in their td or tf research process, and which activities they can safely leave to others. However, the 15 roles identified in this paper could facilitate expectation management, mutual transparency, and clarity of roles undertaken by all actors, as well as guide the selection of professional partners and the recruitment of staff for new td and $\mathrm{tf}$ research processes.

Our research results do not only advance a reflective td and $\mathrm{tf}$ research practice, but might also stimulate future research on roles and activities beyond the researcher-practitioner dichotomy. For example, an interesting subject for future research is whether or not a td or tf research process would be more balanced if non-scientific actors adopted more roles in the realm of BOUNDARY MANAGEMENT. It would also be valuable to cross-check our findings with research reports and other non-peer-reviewed publications and to substantiate them with field studies.

Supplementary Information The online version contains supplementary material available at https://doi.org/10.1007/s11625-021-01028-4.

Funding Open Access funding enabled and organized by Projekt DEAL.

Open Access This article is licensed under a Creative Commons Attribution 4.0 International License, which permits use, sharing, adaptation, distribution and reproduction in any medium or format, as long as you give appropriate credit to the original author(s) and the source, provide a link to the Creative Commons licence, and indicate if changes were made. The images or other third party material in this article are included in the article's Creative Commons licence, unless indicated otherwise in a credit line to the material. If material is not included in the article's Creative Commons licence and your intended use is not permitted by statutory regulation or exceeds the permitted use, you will need to obtain permission directly from the copyright holder. To view a copy of this licence, visit http://creativecommons.org/licenses/by/4.0/.

\section{References}

Biddle BJ (1979) Role theory: expectations, identities, and behaviors. Academic Press

Bracken LJ, Bulkeley HA, Whitman G (2014) Transdisciplinary research: understanding the stakeholder perspective. J Environ Planning Manag 58(7):1291-1308. https://doi.org/10.1080/09640 568.2014.921596

Brundiers K, Wiek A, Kay B (2013) The role of transacademic interface managers in transformational sustainability research and education. Sustainability 5(11):4614-4636. https://doi.org/10. 3390/su5114614

Bulten E, Hessels LK, Hordijk M, Segrave AJ (2021) Conflicting roles of researchers in sustainability transitions: balancing action and reflection. Sustain Sci 3(6):949. https://doi.org/10.1007/ s11625-021-00938-7

Cash DW, Clark WC, Alcock F, Dickson NM, Eckley N, Guston DH, Jäger J, Mitchell RB (2003) Knowledge systems for sustainable development. Proc Natl Acad Sci 100(14):8086-8091. https://doi. org/10.1073/pnas.1231332100

Chilvers J, Longhurst N (2016) Participation in transition(s): reconceiving public engagements in energy transitions as co-produced, emergent and diverse. J Environ Planning Policy Manag 18(5):585-607. https://doi.org/10.1080/1523908X.2015.1110483

Dellwing M, Prus RC (2012) Einführung in die interaktionistische Ethnografie: Soziologie im Außendienst. Lehrbuch. Springer, Berlin

Duncan R, Robson-Williams M, Edwards S (2020) A close examination of the role and needed expertise of brokers in bridging and building science policy boundaries in environmental decision making. Palgrave Commun 6(1):477. https://doi.org/10.1057/ s41599-020-0448-x

Efron SE, Ravid R (2019) Writing the literature review: a practical guide. The Guilford Press

Felt U, Igelsböck J, Schikowitz A, Völker T (2012) Challenging participation in sustainability research. Int J Deliber Mech Sci 1:4-34. https://doi.org/10.17583/demesci.2012.353

Felt U, Ingelsböck J, Schikowitz A, Völker T (2013) Growing into what? The (un-)disciplined socialisation of early stage researchers in transdisciplinary research. High Educ 65(4):511-524. https:// doi.org/10.1007/s10734-012-9560-1 
Fischer LB, Newig J (2016) Importance of actors and agency in sustainability transitions: a systematic exploration of the literature. Sustainability. https://doi.org/10.3390/su8050476

Fritz L, Binder CR (2020) Whose knowledge, whose values? An empirical analysis of power in transdisciplinary sustainability research. Eur J Fut Res 8(1):1593. https://doi.org/10.1186/ s40309-020-0161-4

Harris F, Lyon F (2013) Transdisciplinary environmental research: building trust across professional cultures. J Environ Sci. https://doi.org/10.1016/j.envsci.2013.02.006

Hilger A, Keil A (2021) Education for sustainable development with transdisciplinary-oriented courses - experiences and recommendations for future collaborations in higher education teaching. J Geogr High Educ. https://doi.org/10.1080/03098265.2021.1946765

Hilger A, Rose M, Wanner M (2018) Changing faces-factors influencing the roles of researchers in real-world laboratories. GAIA Ecol Perspect Sci Soc 27(2):138-145

Horlings LG, Nieto-Romero M, Pisters S, Soini K (2020) Operationalising transformative sustainability science through placebased research: the role of researchers. Sustain Sci 15(2):467484. https://doi.org/10.1007/s11625-019-00757-x

Jahn T, Bergmann M, Keil F (2012) Transdisciplinarity: between mainstreaming and marginalization. Ecol Econ 79:1-10. https:// doi.org/10.1016/j.ecolecon.2012.04.017

Kates RW, Clark WC, Corell R, Hall JM, Jaeger CC, Lowe I, McCarthy JJ, Schellnhuber HJ, Bolin B, Dickson NM, Faucheux S, Gallopin GC, Gruebler A, Huntley B, Jäger J, Jodha NS, Kasperson RE, Mabogunje A, Matson P, Svedin U (2001) Sustainability science. Science 292(5517):641-642. https://doi.org/ $10.1126 /$ science. 1059386

Klenk NL, Meehan K (2017) Transdisciplinary sustainability research beyond engagement models: toward adventures in relevance. Environ Sci Policy 78:27-35. https://doi.org/10.1016/j. envsci.2017.09.006

Lang DJ, Wiek A, Bergmann M, Stauffacher M, Martens P, Moll P, Swilling M, Thomas CJ (2012) Transdisciplinary research in sustainability science: practice, principles, and challenges. Sustain Sci 7(S1):25-43. https://doi.org/10.1007/s11625-011-0149-x

Lindsay J, Rogers BC, Church E, Gunn A, Hammer K, Dean AJ, Fielding K (2019) The role of community champions in longterm sustainable urban water planning. Water 11(3):1-14. https://doi.org/10.3390/w11030476

Miah JH, Griffiths A, McNeill R, Poonaji I, Martin R, Morse S, Yang A, Sadhukhan J (2015) A small-scale transdisciplinary process to maximising the energy efficiency of food factories: insights and recommendations from the development of a novel heat integration framework. Sustain Sci 10(4):621-637. https://doi. org/10.1007/s11625-015-0331-7

Miller TR (2013) Constructing sustainability science: emerging perspectives and research trajectories. Sustain Sci 8(2):279-293. https://doi.org/10.1007/s11625-012-0180-6

Miller TR, Wiek A, Sarewitz D, Robinson J, Olsson L, Kriebel D, Loorbach D (2014) The future of sustainability science: a solutions-oriented research agenda. Sustain Sci 9(2):239-246. https://doi.org/10.1007/s11625-013-0224-6

Mobjörk M (2010) Consulting versus participatory transdisciplinarity: a refined classification of transdisciplinary research. Futures 42(8):866-873. https://doi.org/10.1016/j.futures.2010.03.003

Moher D, Liberati A, Tetzlaff J, Altman DG (2009) Preferred reporting items for systematic reviews and meta-analyses: the prisma statement. PLoS Med 6(7):e1000097. https://doi.org/10.1371/ journal.pmed.1000097

Newton A, Elliott M (2016) A typology of stakeholders and guidelines for engagement in transdisciplinary, participatory processes. Front Mar Sci. https://doi.org/10.3389/fmars.2016. 00230
Ober S, Paulick-Thiel C, Köppen E (2019) Einbindung von PraxispartnerInnen in transdisziplinären Forschungsprojekten: Herausforderungen und Empfehlungen. Nachhaltiges Wirtschaften - NaWiKo Synthese Working Paper No 4

Pohl C, Rist S, Zimmermann A, Fry P, Gurung GS, Schneider F, Speranza CI, Kiteme B, Boillat S, Serrano E, Hadorn GH, Wiesmann U (2010) Researchers' roles in knowledge co-production: experience from sustainability research in kenya, Switzerland, bolivia and nepal. Sci Public Policy 37(4):267-281. https://doi. org/10.3152/030234210X496628

Reed MS, Vella S, Challies E, de Vente J, Frewer L, HohenwallnerRies D, Huber T, Neumann RK, Oughton EA, Sidoli del Ceno J, van Delden H (2018) A theory of participation: what makes stakeholder and public engagement in environmental management work? Restor Ecol 26:S7-S17. https://doi.org/10.1111/ rec. 12541

Rose M, Maibaum K (2020) Meeting the challenge of (co-)designing real-world laboratories: insights from the well-being transformation wuppertal project. GAIA Ecol Perspect Sci Soc 29(3):154160. https://doi.org/10.14512/gaia.29.3.5

Sarkki S, Heikkinen HI, Karjalainen TP (2013) Sensitivity in transdisciplinary projects: a case of reindeer management in Finland. Land Use Policy 34:183-192. https://doi.org/10.1016/j.landu sepol.2013.03.004

Schäpke N, Stelzer F, Bergmann M, Lang DJ (2016) Tentative theses on transformative research in real-world laboratories: first insights from the accompanying research forreal. Technikfolgeabschätzung Theorie Und Praxis 25(3):45-51

Schauppenlehner-Kloyber E, Penker M (2015) Managing group processes in transdisciplinary future studies: how to facilitate social learning and capacity building for self-organised action towards sustainable urban development? Futures 65:57-71. https://doi.org/ 10.1016/j.futures.2014.08.012

Schimank U (2016) Handeln und Strukturen: Einführung in die akteurtheoretische Soziologie (5, revised edition). Grundlagen der Soziologie. Beltz Juventa

Schneidewind U, Augenstein K (2016) Three schools of transformation thinking: the impact of ideas, institutions, and technological innovation on transformation processes. GAIA Ecol Perspect Sci Soc 25(2):88-93. https://doi.org/10.14512/gaia.25.2.7

Schneidewind U, Singer-Brodowski M, Augenstein K, Stelzer F (2016) Pledge for a transformative science: a conceptual framework (Wuppertal Paper No. 191). Wuppertal

Scholz RW (2017) The normative dimension in transdisciplinarity, transition management, and transformation sciences: new roles of science and universities in sustainable transitioning. Sustainability. https://doi.org/10.3390/su9060991

Scholz RW (2020) Transdisciplinarity: science for and with society in light of the university's roles and functions. Sustain Sci 23(3):245. https://doi.org/10.1007/s11625-020-00794-x

Scholz RW, Steiner G (2015a) The real type and ideal type of transdisciplinary processes: part I - theoretical foundations. Sustain Sci 10(4):527-544. https://doi.org/10.1007/s11625-015-0326-4

Scholz RW, Steiner G (2015b) The real type and ideal type of transdisciplinary processes: part ii - what constraints and obstacles do we meet in practice? Sustain Sci 10(4):653-671. https://doi.org/ $10.1007 / \mathrm{s} 11625-015-0327-3$

Snyder H (2019) Literature review as a research methodology: an overview and guidelines. J Bus Res 104:333-339. https://doi.org/10. 1016/j.jbusres.2019.07.039

Stauffacher M (2010) Beyond neocorporatism? Transdisciplinary case studies as a means for collaborative learning in sustainable development. In: Gross M, Heinrichs H (eds) Environmental sociology. Springer, Berlin

Stauffacher M, Scholz RW (2012) Transdisziplinäre Lehrforschung am Beispiel der Fallstudien der ETH Zürich. In: Dusseldorp M, 
Beecroft R (eds) Technikfolgen abschätzen lehren: Bildungspotenziale transdisziplinärer Methoden. Springer VS, pp 277-291

Stauffacher M, Flüeler T, Krütli P, Scholz RW (2008) Analytic and dynamic approach to collaboration: a transdisciplinary case study on sustainable landscape development in a swiss prealpine region. Syst Pract Action Res 21(6):409-422. https://doi.org/10.1007/ s11213-008-9107-7

Stoecker R (1999) Are academics irrelevant? roles for scholars in participatory research. Am Behav Sci 42(5):840-854. https://doi.org/ 10.1177/00027649921954561

United Nations Conference on Environment and Development (1992) Agenda 21: Programme of action for sustainable development. Rio declaration on environment and development. Statement of forest principles; the final text of agreements negotiated by governments at the United Nations Conference on Environment and Development (UNCED), 3-14 June 1992, Rio de Janeiro, Brazil (2. print). Department of Public Information United Nations

VERBI Software (2019) MAXQDA 2020 [Computer software]. VERBI Software, Berlin

VERBI Software (2020) MAXQDA 2020 Manual. Berlin. https://www. maxqda.com/help-mx20/welcome

Wanner M, Hilger A, Westerkowski J, Rose M, Schäpke N, Stelzer F (2018) Towards a cyclical concept of real-world laboratories: a transdisciplinary research practice for sustainability transitions. DisP Plan Rev 54(2):94-114

Wesselink A, Paavola J, Fritsch O, Renn O (2011) Rationales for public participation in environmental policy and governance: practitioners' perspectives. Environ Plan A 43(11):2688-2704. https://doi. org/10.1068/a44161

Wiek A (2007) Challenges of transdisciplinary research as interactive knowledge generation? Experiences from transdisciplinary case study research. GAIA Ecol Perspect Sci Soc 16(1):52-57. https:// doi.org/10.14512/gaia.16.1.14

Wittmayer JM (2016) Transition management, action research and actor roles: understanding local sustainability transitions. Erasmus University Rotterdam

Wittmayer JM, Schäpke N (2014) Action, research and participation: roles of researchers in sustainability transitions. Sustain Sci 9(4):483-496. https://doi.org/10.1007/s11625-014-0258-4

Wittmayer JM, Avelino F, van Steenbergen F, Loorbach D (2017) Actor roles in transition: insights from sociological perspectives. Environ Innov Soc Trans 24:45-56. https://doi.org/10.1016/j.eist. 2016.10.003

Publisher's Note Springer Nature remains neutral with regard to jurisdictional claims in published maps and institutional affiliations. 